\title{
ТОПОНИМЫ КАК МАРКЕРЫ ДИАЛЕКТОВ И ГОВОРОВ ТУВИНСКОГО ЯЗЫКА *
}

\section{Мира В. Бавуу-Сюрюн}

Тувинский государственный университет, Российская Федерация

\section{PLACE NAMES AS MARKERS OF THE DIALECTS AND SUB- DIALECTS OF TUVAN LANGUAGE}

\author{
Mira V. Bavuu-Surun \\ Tuvan State University, \\ Russian Federation
}

В работе предлагается топонимы рассматривать как маркеры диалектов и говоров тувинского языка, что является новым взглядом на топонимию Тувы.

Тувинский язык территориально делится на следующие диалекты и говоры: изентральный диалект с дзун-хемчикским, эрзинскотес-хемским, улуг-хемским, овюрским и тандынским говорами; западный диалект с бай-тайгинско-барун-хемчикским, монгунтайгинским, кара-хольским говорами; терехольский, тоджинский, цагаан-нурский диалекты; алтайский диалект с кобдоским, изэгэльским, китайским говорами. Современные диалектные черты тувинского языка являются результатом как междиалектных, так и межвязыковых связей, развитием собственных ресурсов.

Топонимия Тувы в целом отражает состояние языковых контактов: центральный и западный диалекты с его говорами занимает обширную территорию современной Тувы, где в основном фиксируется общетюркская, собственно тувинская по происхождению топонимы, они прозрачны в своей

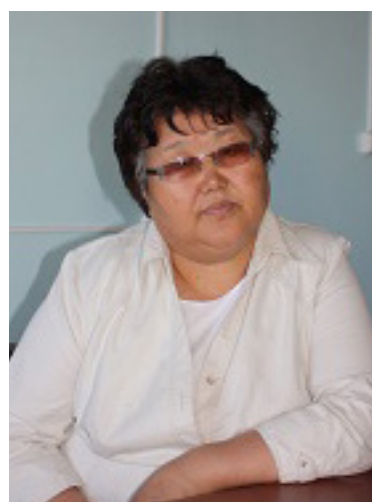

In this article we propose that place names should be considered markers of the dialects and subdialects of the Tuvan language, which is a new perspective on the toponymy of Tuva.

Tuvan language is divided into the following dialects and subdialects: the Central dialect with Dzun-khemchik, Erzin-tes-khem, Ulug-khem, Ovyur and Tandyn sub-dialects; the Western dialect with Bai-taiga-barun-khemchik, Mongun-taiga, Kara-hol subdialects; Tere-hol, Todzha, Tsagaan-nur dialects; and finally, Altai dialect with Kobdo, Tsengel and Chinese sub-dialects. The modern dialect features of Tuvan language are a result of both interdialectal and interlanguage contacts and development of the language's own resources.

The place names of Tuva reflect a state of the language relations: the Central and the Western dialect with their sub-dialects occupy the vast

\footnotetext{
* Работа выполнена в соответствии с планом научно-исследовательских работ Государственно$2 о$ задания Министерства образования и науки Российской Федерации № 1.4539.2017/8.9 (nроект № 34.3876.2017/ПЧ) / The article was written in accordance with the plan of research works of the State task of the Ministry of education and science of the Russian Federation No. 1.4539.2017/8.9 (project No. 34.3876.2017/HR

Бавуу-Сюрюн Мира Викторовна - кандидат филологических наук, доцент; ведущий научный сотрудник научно-образовательного центра «Тюркология» Тувинского государственного университета. Адрес: 667000, г. Кызыл, ул. Ленина, д. 36. Тел.: +7 (394-22)-2-19-69. Эл. адрес: mira.bavuu_surun@ mail.ru

Bavuu-Surun Mira Viktorovna, Candidate of Philology, Associate Professor, Leading Researcher, Research and Education Center of Turkic Studies, Tuvan State University. Postal address: 36 Lenin St., 667000 Kyzyl, Russian Federation. Tel.: +7 (394-22) 2-16-69.E-mail:mira.bavuu_surun@mail.ru
} 
этимологии. Редкие монголизмы-топонимы, встречающиеся на территории распространения центрального и западного диалектов отражают исторически сложившиеся тюрко-монгольские языковые связи. Более плотно расположены микротопонимы монгольского происхождения на юго-восточной территории Тувы, в особенности ареалы распространения эрзино-тес-хемского говора и терехольского диалекта. Территория распространения тоджинского диалекта отличается от других территорий сложными топонимами с древнетюркскими компонентами, не встречающимися на других территориях распространения тувинского языка, топонимами, отражающими богатство флоры $и$ фауны таёжной тайги.

Эндемик-аппелятив хем объединяет воедино те территории Монголии и Китая, где издревле живут этнические тувинцы - носители иэнгэльского и китайского говоров; а также приграничные с Тувой территории Горного Алтая, где ассимилировали некогда тувиноязычные родоплеменные группы. На территориях распространения зарубежных диалектов топонимия отличается параллельными тувинско-казахскими, тувинско-монгольскими названиями одного и того же объекта; тувинскорусскими параллельными названиями характеризуются территории цзентрального диалекта, где с начала XX века стали селиться староверы.

Ключевые слова: тувинский язык; топонимика; Тува; параллельные названия; языковые процессы; диалект тувинского языка; аппелятив; монгольский язык; русский язык territory of the modern Tuva, where the Turkic and original Tuvan toponyms are found, which are clear in their etymology. Rare mongolisms toponyms occurring in the territory of Central and Western dialects - reflect historical TurkicMongolian language connections. Micro-toponyms of the Mongolian origin are located more densely in the south-east of the modern Tuva, especially in the areas where Erzin-tes-khem sub-dialect and Tere-hol dialect are spoken. The Todzha dialect area is known for its complex toponyms, including components of the ancient Turkic origin, which do not occur in other areas of Tuvan language. These toponyms reflect the richness of the flora and fauna of the taiga.

The endemic appellative "khem" unites Mongolian and Chinese territories which have always been home for ethnic Tuvans - native speakers of Tsengelsky and Altai sub-dialects. This area also covers the border territories between Tuva and Gorny Altai, where over time Tuvan tribal groups were assimilated. Finally, in the areas where foreign dialects of Tuvan are spoken, toponymy has developed parallel Tuvan-Kazakh or TuvanMongolian names for the same location; while Tuvan-Russian parallel names appear in the territories of the Central dialect, where the Old Believers began to settle down since the beginning of the 20th century.

Keywords: Tuvan language; toponymy; Tuva; parallel names; language processes; dialect of the Tuvan language; appellative; Mongolian language; Russian language

\section{Введение}

Тува, как географический центр Азии, в своей топонимии отражает все те языковые контакты, происходившие на данной территории с древнейших времен. Таким же образом складывалась и диалектная система современного тувинского языка. В имеющихся работах по топонимии Тувы авторы либо изучали особенности топонимии отдельных территорий Тувы, либо следы языковых контактов в топонимии Тувы.

Мы же предлагаем топонимы рассматривать как маркеры диалектов и говоров тувинского языка, что является новым взглядом на топонимию Тувы. Безусловно, в своей работе мы опирались на труды Б. К. Ондар (Ондар, 2007, 2008, 2011), которые имеют непреходящее значение. В них собран, систематизирован и представлен в сопоставлении самый значительный топонимический материал. Большое значение имеют этимологические изыскания Б. И. Татаринцева (Татаринцев, 1977ab, 1993) по топонимам Тувы. Также в качестве источников привлечен полевой материал, собранный автором 
во время экспедиций с 1990-х годов в места компактного проживания тувинцев за рубежом и по Туве. Привлекался также языковой материал, собранный на территории Горного Алтая О. Т. Молчановой (Молчанова, 1977, 1979, 1982). Диалектное членение тувинского языка в настоящей работе представлено по результатам исследований автора (Бавуу-Сюрюн, 2018).

Поскольку речь идёт о топонимах как маркерах диалектной речи, при наличии разного написания тех или иных топонимов, мы брали названия, характерные для устной речи местных жителей. Названия, распространенные на территориях распространения тувинского языка за рубежом, были орфографированы по правилам современного тувинского языка с сохранением особенностей диалектного произношения.

\section{Система диалектов и говоров тувинского языка}

Тувинский язык относится к младописьменным языкам России.

Основная территория распространения тувинского языка - Республика Тыва, один из субъектов Российской Федерации, расположена южнее Красноярского края; на западе граничит с Республикой Горный Алтай, на северо-востоке - с Иркутской областью, Бурятией, а юго-восточная часть республики граничит с Монголией.

Тувинский язык территориально распространен также на территории северо-западной Монголии и на крайнем северо-западе Китая, где проходит граница Монголии, России, Казахстана. Такое распространение диалектов и говоров тувинского языка обусловлено историческими факторами.

Тува до 1912 г. находились в составе Циньской китайской империи. Ориентация на Россию установилась после 1914 г., когда Тува, после падения Цинской империи и нескольких лет самоопределения как бывшая колония, обратилась за помощью к России и получила ее протекторат. А в 1921 г. под влиянием Октябрьской социалистической революции местное национальноосвободительное движение провозгласило Тувинскую Народную Республику. Эта республика просуществовала с 1921 по 1944 г., пока Тува не вошла в состав СССР на правах автономной области, затем - уже как автономная республика.

Изменение геополитической ситуации в начале XX века с востока на запад в жизни основной части тувинского этноса отразилось и в целом в литературном тувинском языке, в частности в формировании современных его диалектов и говоров. В силу исторических обстоятельств китайские тувинцы оказались оторванными от наших основных территорий гораздо раньше, чем тувинцы Монголии. Тувинцы Китая и основная часть тувинцев Монголии называют себя алтайскими тувинцами (Маннай-оол, 2004: 110), так как исторически алтайская горная гряда находится на стыке границ трех государств: Монголии, Китая, России. 
Отметим, что наша работа охватывает гораздо обширные территории, потому что многие диалектные черты в свои ареалах уходят за пределы распространения тувинского языка: на территории Горного Алтая на западе, на севере в Хакасию, на территории западной Сибири; Иркутскую область, где живут тофалары; на территории Монголии и Бурятии, где живут сойоты, уйгурурянхайцы. Такая обширная территория распространения тувинского языка с его связями с близкородственными языками представлена впервые.

Территории в Селенгинском и Центральном аймаках, где компактно проживают этнические тувинцы с 60-70-х годов XX века, представлены одним цэнгэльским говором, принадлежащим алтайскому диалекту. Носители цааганнурского диалекта - в основном переселенцы из Тувы. История их переселения охватывает буквально недавний период - 1950-1960 гг. Они окончательно остались в Монголии. Это кочевые таежные оленеводы, которые испокон веков кочуют на своих территориях в силу того, что были проведены государственные границы, и уже нельзя было беспрепятственно её переходить как раньше. Таким образом они оказались оторванными от материнского этноса и в какой-то части перешли на оседлый образ жизни. Это позволило образоваться отдельному диалекту, который сложился в результате конвергентного и дивергентного развития разных диалектов тувинского языка за пределами современной Тувы.

Диалектное членение тувинского языка произведено на основе совокупности лингвистических признаков, так как в тувинском языке нет четко противопоставленных критериев, явно очерченных ареалов распространения диалектных различий.

При выделении диалектов рассматривались различия в области фонетики, лексики, грамматики от литературного тувинского языка и других диалектов. Говоры выделены в составе диалектов на основе сопоставления как с литературным языком, так и с говорами в составе одного диалекта. В диалектном отношении тувинский язык, на территории проживания основной массы носителей языка, более однороден, чем на тех территориях, которые оказались оторванными в силу природных препятствий, исторических событий. Традиционные интенсивные контакты диффузного характера, социальноэкономические связи способствовали формированию в центральной части Тувы диалектов с небольшими диалектными различиями.

На основе совокупности лингвистических данных мы выделили:

- центральный диалект с дзун-хемчикским, эрзин-тес-хемским, улугхемским, овюрским и тандынским говорами;

- западный диалект с бай-тайгинско-барун-хемчикским, монгунтайгинским, кара-хольским говорами;

- тере-хольский диалект;

- тоджинский диалект; 
- цагаан-нурский диалект;

- алтайский диалект с кобдоским, цэнгэльским, китайским говорами.

Диалекты и говоры характеризуются как сохранившимися из древнеуйгурского, древнекыргызского, древнеогузского языков реликтовыми чертами, так и инновационными чертами, появившимися под влиянием языковых контактов разного уровня.

Современные диалектные черты тувинского языка являются результатом как междиалектных, так и межъязыковых связей, развитием собственных ресурсов.

В плане проявления диалектных черт, обусловленных языковыми контактами разного характера, западный диалект имеет общие черты с алтайским, шорским языками и алтайским диалектом тувинского языка. Тоджинский, цагаан-нурский и тере-хольский диалекты проявляют общность с тофаларским, сойотским и уйгур-урянхайским языками. Эрзинско-тес-хемский говор более подвержен монгольскому влиянию, чем остальные внутренние диалекты и говоры; в этом он близок с зарубежными диалектами. Изолированные диалекты и говоры сохраняют больше архаичных черт, чем диалекты и говоры, распространенные в центральной части Тувы.

Монгольское влияние на диалекты и говоры имеет разновременный характер, в своих отдельных чертах отличается от влияния на литературный тувинский язык. Монгольский язык оказал мощное влияние на все уровни литературного тувинского языка, поэтому заметен монгольский слой и в топонимии Тувы.

На основе экстралингвистических факторов диалекты группируются как внутренние и зарубежные; степные, таёжные и таежно-степные. С учетом возможностей коммуникации мы фиксируем изолированные тоджинский и тере-хольский диалекты наряду с зарубежными диалектами. Наличие письма на родном языке характеризует внутренние диалекты как функционирующие при наличии письменности на родном языке, а зарубежные диалекты - как функционирующие при отсутствии письменности на родном языке, кроме цэнгэльского говора, где только в конце XX века началось обучение на тувинском языке, созданы учебники для начальной школы.

Нижней границей начала формирования диалектных черт следует признать время существования древних тюркских языков, от которых сохранились отдельные языковые явления, фиксируемые в современных диалектах и говорах тувинского языка.

Важными для ареальных исследований являются свидетельства о местах расселения тувинских племен в разное время. Из «Истории Тувы» известно, что «тувинские племена в XVII - первой половине XVIII в. занимали более обширную территорию: южнее - до г. Кобдо - и восточнее - до оз. Хубсугул и 
по северной стороне Саян через Алтай и Минусинскую котловину до верховьев рек Урунгу, Черного Иртыша и г. Томска» (История Тувы, 2001: 303).

О территории распространения тувинского языка и его носителей в конце XIX века писал известный тюрколог В. В. Радлов, побывавший в Западной Туве в 1861 г., в своём дневнике «Из Сибири»: «...общее название сойонов - туба (один из фонетических вариантов этнонима «тыва». - M. Б.-С.) и ... живут они значительными массивами вдоль границы Сибири, начиная с истока реки Кобдо у Кемчика и в системе Улу-Кем до Косогола и восточнее Косогола до Тункинской степи и системы Селенги» (Радлов, 1989: 99).

Озеро Хубсугул (по Радлову, Косогол) находится на территории Монголии и на его северо-западной части живут тувинцы-оленеводы.

Как видно, тувинские племена занимали обширные территории Центральной Азии. Рассмотрим те территории, которые наиболее интересны в плане языковых контактов.

\section{Особенности топонимии Тоджинского кожууна и сопредельных территорий}

Топонимия данной территории была объектом пристального внимания Б.И. Татаринцева (Татаринцев, 1993). Обращает внимание наличие ряда названий с компонентом Оо: Биче-Оо, Улуг-Оо, Оо-Даш, Оо-Тайга, Биче-Оо, Кадыр-Оо. По мнению Б. И. Татаринцева, он является географическим термином тюркского происхождения со значениями 'пропасть, глубокое место, размытое водой, низменность, омут, водоворот’ от глагольной основы оп уп 'пожирать, втягивать, всасывать, оседать (о почве во время землетрясения); проваливаться (о земле)' (там же: 108-109).

Ряд географических объектов, в названиях которых встречается слово чул от древнетюркского слова jul - ‘источник, ручей’ (Древнетюркский словарь, 1969: 277) , встречается вдоль границы Тувы с Хакасией: на Тодже - Диињ-Чул (Ондар, 2007: 195), Чумуртуг-Чул (там же: 499); на территории сумона Кара-Хөл Бай-Тайгинского кожууна - Чулча - исток реки Алаш; в Сут-Хольском кожууне названия рек - Талдыг-Чул, Кызыл-Чул. Б. К. Ондар считает, что компонент чул в топонимии Тувы заимствован из хакасского языка (Ондар, 2008: 69)

На территории Тоджинского кожууна обнаруживается топоним Өдүген, упоминаемый в древнетюркских памятниках (Ондар, 2007: 330-331).

Тоджинский диалект отличается наличием развитой охотничье-рыболовной лексики, они присутствуют в многочисленных топонимах, производных от них: Буурлуг, Диицчи-Суг, Дунчулуг-Хем, Соруг, Ирелиг, Ирелиг-Даг, Кара-Бальк, Ыт-Хем, Хелескелиг, Мезилдиг-Хөл, Дайырганныг - лит. Дажырганныг - 'озеро, 
по берегам которой водится пищуха' (там же: 183), Даттыг-Балык-Хөл - 'с ржавчиной рыбное озеро, возможно, рыбное, с выходами железа, озеро’ (там же: 184). Особенности растительности и геоморфологии таёжной местности показывают топонимы Оргу-Пөш, Чойган-Хөл, Чойган-Хем, Шеңнелиг; ТазарамаТайга, Дерби-Тайга, Тоңгул-Тайга, Мыя-Хаш и др.

В этом отношении топонимия Тоджи соотносима с топонимией Восточных Саян, где проживают тофалары. Наиболее полным списком топонимов в языке тофаларов можно познакомиться в приложении тофаларско-русского словаря, составленного В. И. Рассадиным (Рассадин, 2016: 598-605).

В топонимах Кадыр-Өөс, Кадыр-Өөс-Хөл, Улуг-Кадыр-Өөс компонент өөс характерен только для Тоджи и Каа-Хема. По мнению Б. И. Татаринцева, данный аппелятив происходит от древнетюркского слова өгүс - 'река' (Татаринцев, 1977b: 89), такое же объяснение со ссылкой на Б. И. Татаринцева и Н. Г. Доможакова даёт Б. К. Ондар (Ондар, 2008: 57). Гидронимы Казас, Азас, Додот, ДодотХөл, по мнению С. И. Вайнштейна (Вайнштейн, 1961: 22), являются топонимами кетского происхождения. Что касается топонима Додот, то его происхождение, по мнению О.Т. Молчановой, является монгольским и переводится с монгольского как ‘близкий’ (Молчанова, 1973: 139). Согласно гипотезе В. М. Наделяева, артикуляционно-акустическая база языка принадлежит этносу, он и проносит свою базу через всю историю своего развития (Наделяев, 1986: 59). Поэтому, если предположить, что эти топонимы сохранились от предыдущего населения Тоджи, то они жили на этой территории по крайней мере до древних уйгур, которые отюречили предков тувинцев (Наделяев, 1986: 58-59). Надо сказать, кроме этих слов других доказательств об иноязычности происхождения местных жителей нет.

Территория Тоджинского кожууна, откуда ушла часть цагаан-нурских тувинцев, характеризуется отсутствием топонимов монгольского происхождения, за исключением приграничных с Монголией части; но наличием некоторых топонимов нетюркского происхождения (кетских) (Татаринцев, 1973: 142-143). Основная масса топонимов Тоджи тюркского происхождения, в них фиксируются собственно тувинские, заимствованные с хакасского языка компоненты. Встречаются названия с нехарактерными для других территорий Тувы компонентами. Таким образом, топонимия Тоджи, проявляя языковое своеобразие коренных жителей данной местности, в то же время является в основном тюркской по происхождению, как и по всей Туве; тесно связана с топонимией хакасского и тофаларского языков.

Язык тувинцев-оленеводов Цагаан-Нура мы называем цагаан-нурским диалектом тувинского языка. Диалект распространен на территории сумона Цагаан-Нур Хубсугульского аймака, в северо-западной части оз. Хубсугул, у оз. Цагаан-Нур (Ак-Хөл), от него берет начало р. Каа-Хем (на монгольской территории имеет название Шигшид-Гол). Озеро, на берегу которого стоит 


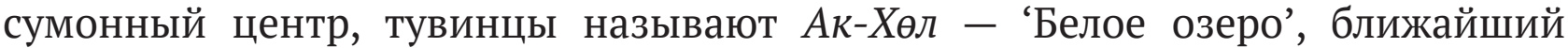
населенный пункт, где ранее проживали - Кызыл-Даг - 'Красная гора', которые имеет официальные названия на монгольском языке Цагаан-Нур 'Белое озеро’ и Улаан-Уул - 'Красная гора'. Таким образом, на территории Хубсугульского аймака можно встретить тюрко-монгольские параллельные топонимы, свидетельствующие об истории заселения данной территории. Понятно, что на картах и на других письменных источниках преобладают монгольские названия. Самое крупное пресноводное озеро Хубсугул имеет и другое написание на монгольском языке - Хөвсгөл, на тувинском название озера звучит как Көn-Суг-Хөл. Этимология топонима на почве тувинского языка прозрачна (букв.: много - вода - озеро) «многоводное озеро», равно как и озера Байкал > Бай-Хөл - ‘богатое озеро’.

Особенности топонимии юга Тувы, куда входят территории распространения овюрского, монгун-тайгинского и эрзинско-тес-хемского говоров. Эта территория более подвержена монгольскому влиянию, чем остальные внутренние диалекты и говоры. Список топонимов монгольского происхождения, собранный по письменным источникам в алфавитном порядке, был представлен в работе О. Т. Молчановой «Монгольский слой в топонимии Тувы» (Молчанова, 1973). Структура топонимов монгольского происхождения на территории Тувы была исследована нами ранее (Бавуу-Сюрюн, 2005).

Более плотное расположение объектов, названные топонимами монгольского происхождения, фиксируется на юго-восточной Туве: Мөрен, Нарын, Ямаалык, Дархи, Цагаан-Тологой, Цухер-Элс, Качык, Шара-Нур, Убса-Нур, ДахууНур (Ондар, 2007: 184) - 'озеро вдоль русла реки’.

Гораздо меньше, но все же фиксируются топонимы-монголизмы в говорах, распространенных на приграничных с Монголией территориях на юго-западе. На территории Монгун-Тайгинского кожууна, особенно в нижнем течении реки Мөген-Бүрен (монголизм) фиксируются топонимы-монголизмы: Acnambl, Мөзұтү. В Овюрском кожууне - Хандагайты, Саглы, Улаатай.

\section{Топонимы в языке алтайских тувинцев}

У тувинцев Китая нами зафиксированы топонимы: Ээви-Хем, ДураганКем, Туруун-Хем, Хайырты-Хем, Үлүнгу, Сундарык-Хем, Кирин-Хем, Хом, Ханас (река и озеро), Бош-Даг, Болбаадай, Алдай, Буурул-Догай, Көк-Догай, Ак-Хава, Чеди-Хава, Кыр, Ала-Хаак, Дөрелчи // Дөрөлчи, Хүрээлиг, Теректиг, Аргальг, Тарааты // Тараалыг, Чипкелиг // Чекпелиг, Бууржу // Бурчин, Алдынак аршаан, Депсек-чурту (күзег), Кызыл-Соян кыштак, Өлгүн-Бажы чайлаг, Кара-Сайыр, Майган-Даш, Оруктуг, Кадыылыг, Хөңделең, Чадальг, Доора-Даг, Хорумнуг. За исключением отдельных топонимов (Дөрелчи, Сундарык, Ханас) их семантика прозрачна, поэтому такие топонимы можно считать собственно тувинскими 
по происхождению. Из списка видно, что в гидронимах используется в качестве топоформанта слово хем // кем, где в анлауте наличествует общетюркское звуковое соответствие $\mathrm{x}^{\sim}$ к. Эти слова безусловно относятся к тувинским наименованиям. Макротопонимы данного ареала на китайском в транслитерации звучат как: Хом - Хоме, Ханас - Канасе, Алдай - Алэтаи, Бууржу - Бууржин, Ала-Хаак - Алагак. Все они, в основном, являются гидронимами, вторичными топонимами, то есть названиями населенных пунктов, возведенных в бассейнах этих рек и озера Ханас. Тувинские микротопонимы функционируют в устной речи тувинцев.

Территория сумона Цэнгэл Баян-Улэгэйского аймака Монголии также отличается от других территорий Монголии наличием большого количества топонимов с аппелятивами даг - 'гора', хөл - 'озеро', хем - 'река': Ак-Хем, Харааты-Хем, Хураган-Хем, Кодан-Хөл, Кара-Хөл, Сарыг-Хөл, Бай-Даг и т. д., что характеризует данную территорию как исконно тюркоязычную. В то же время данный ареал отражает ту языковую ситуацию, сложившуюся в настоящее время: появление казахского населения в начале XX столетия и постепенное его численное преобладание привело к тому, что идёт ассимиляция цэнгэльского говора под влиянием казахского языка (БавууСюрюн, 2011: 30). В этом отношении топонимия данного ареала также имеет свои особенности функционирования, которое заключается в том, что один и тот же географический объект может иметь тувинское и казахское название: тув. Шокар-Арга - каз. Шыбар-Карагай, тув. Теве-Моюн - каз. Түе-Мойнак, тув. Хара-Даг - каз. Кара-Тау; тув. Коданныг - каз. Шакен, тув. Дугдектиг - каз. Кемелек, тув. Куп-Суг - каз. Ит-Көзен (Баярсайхан, 2000: 23-24).

Они являются либо прямым переводом тувинских названий на казахский: тув. Теве-Моюн - каз. Түе-Мойнак, тув. Хара-Даг - каз. Кара-Тау; либо казахское название местности: тув. Коданныг - каз. Шакен, тув. Дугдектиг - каз. Кемелек, тув. Куп-Суг - каз. Ит-Көзен.

Вторая особенность данного ареала состоит в том, что на географических картах тувинские названия переведены на монгольский язык: тув. СарыгХову - монг. Шар говь, тув. Улуг-Даг - монг. Их уул, тув. Чыланныг - монг. Могойт, тув. Хара-Адыр - монг. Хар салаа, тув. Хураган-Хөл - монг. Хурган нуур, тув. Тожантыг - монг. Тошонт (там же).

В силу специфики данного пласта лексики чаще всего топонимы-монголизмы фиксируются там, где имеют место маргинальные языковые контакты: в приграничных территориях, а также на тех исторических территориях компактного проживания тувинцев за рубежом. Практически единичные тувинские названия местностей фиксируются в языке тувинцев, которые живут на территории сумона Цагаан-Нур. В ареалах распространения кобдоского говора, в местах проживания тувинцев Сэлэнги не было записано ни одного тувинского топонима, они есть в народных песнях алтайских тувинцев. Это 
ещё раз подтверждает то, что современные тувинцы в указанных территориях являются пришлым населением с недавней историей.

\section{Русская топонимия Тувы}

Это явление позднее, она представлена в основном микротопонимами в местах заселения староверов: Бии-Хемский, Тандинский, Кызыльский, Каа-Хемский, Улуг-Хемский кожуунах (Ондар, 2011: 3-4), то есть ареал распространения центрального диалекта. В своей соответствующей работе Б. К. Ондар в этот ареал включает территорию Тоджинского кожууна. Нам бы хотелось уточнить, что русские топонимы фиксируются в ареале распространения речного говора. Всего по списку, представленной в работе Б. К. Ондар, насчитывается 479 названия. Особенность топонимии указанного ареала состоит в том, что в нем бытуют тувинско-русские параллельные топонимы. Характерна в этом отношении территория Каа-Хемского кожууна, где многие населенные пункты имеют два наименования: Бурен-Хем - Зубовка, Кундустуг - Фёдоровка, КоптуАксы - Бояровка, Көк-Хаак - Медведевка, Дерзиг-Аксы - Даниловка, БуренАксы - Грязнуха. В Тандынском кожууне Арыг-Бажы - Владимировка, Дус-Хөл Сватиково.

Русские названия имеют всего несколько сёл: Сосновка, Кочетово, Успенка в Тандынском кожууне, Чкаловка, Ленинка в Бии-Хемском кожууне, Ильинка - в Каа-Хемском. Основная масса русских названий местностей - микротопонимы.

Особую группу топонимов составляют онимы с искаженным фонетическим обликом: Желома - Чалама, Ергаки - Эргек-Дыргак тайгазы, Блялик - Билелиг, Балгазик - Балгазын, Гагуль - Каа-Хөл по ним трудно установить семантически мотивированный признак, поэтому в топонимических исследованиях, особенно на этапе сбора материала, необходимо получить материалы у коренного населения.

\section{Заключение}

По данным топонимии, территории проживания тувинского этноса в первую очередь характеризуется наличием топонимов с компонентом хем. Он присутствует в сложных названиях рек в основном в Туве и в южных районах Горного Алтая. Впервые эту особенность топонимии Тувы отметил Мурзаев, хотя он ошибочно считает, что слово хем используется исключительно как аппелятив в составе сложных топонимов (Мурзаев, 1974: 107, 184-185). В тувинском языке это полнозначное слово в значении 'река' (Тувинско-русский словарь, 1968: 473).

Топонимы с аппелятивом хем - 'река' встречаются повсеместно там, где исторически тувинцы являются коренными жителями: на всей территории 
Тувы, на юге Красноярского края, сумона Цэнгэл Баян-Улэгэйского аймака Монголии, крайнем северо-западе Китая. Наличие топонимов с подобным топоформантом на прилегающих к Туве территориях Горного Алтая может указывать на тувинский этнический компонент, ассимилированный в языковом отношении. Об этом же указывал М. Х. Маннай-оол в своей работе «Тувинцы: происхождение и формирование этноса» (Маннай-оол, 2004: 124-125).

На основании вышеизложенного можно заключить, что совершенно верно считать тюркский язык, распространенный в указанных ареалах, принадлежит одному этносу, и их местные разновидности - диалектами тувинского языка. Топонимия ареалов проживания носителей диалектов и говоров тувинского языка в целом отражают те языковые процессы и контакты, которые обнаруживаются в диалектах и говорах, и в какой-то мере являются их маркерами.

\section{СПИСОК ЛИТЕРАТУРЫ}

Бавуу-Сюрюн, М. В. (2005) Структура топонимов монгольского происхождения на территории Тувы // Проблемы этнокультурных связей монгольских и тюркских народов / Сампилдэндэв Х. и др. ; отв. ред. А. Л. Ангархаев. Улан-Удэ : ГУП «ИД «Буряад үнэн». 351 с. С. 233-237.

Бавуу-Сюрюн, М.В. (2011) Пути формирования зарубежных диалектов тувинского языка // Актуальные проблемы диалектологии языков народов России : материалы XI межрегиональной конференции (Уфа, 19-21 октября 2011 г.) / [сост.: Р. Н. Каримова]. Уфа : ИИЯЛ УНЦ РАН. 213 с. С. 30-32.

Бавуу-Сюрюн, М. В. (2018) История формирования диалектов и говоров тувинского языка : автореф. дисс. ... докт. филол. наук. Новосибирск. 49 с.

Баярсайхан, Б. (2000) Топонимы на территории сумона Цэнгэл в Монголии (на тувинском языке) // Становление и развитие науки в Туве. (Материалы Межд. конференции, посв. 70-летию тувинской письменности 12-14 сентября 2000 г.) : в 2 ч. Кызыл : РИО ТувГУ. Ч. 1. 140 с. С. 23-25.

Вайнштейн, С. И. (1961) Тувинцы-тоджинцы. М. : Изд-во «Восточная литература». 217 с.

Древнетюркский словарь (1969) / ред. В. М. Наделяев и др. Л. : Наука. 676 с.

История Тувы (2001) : в 2 т. 2-е изд., перераб. и доп./ под ред.С.И. Вайнштейна, М. Х. Маннай-оола. Новосибирск : Наука. Т. I. 367 с.

Маннай-оол, М. Х. (2004) Тувинцы: происхождение и формирование этноса. Новосибирск : Наука. 166 с.

Молчанова, О. Т. (1973) Монгольский слой в топонимии Тувы // Происхождение аборигенов Сибири и их языков : Материалы Всесоюзной конференции 14-16 июня 1973 г. Томск : Изд-во Томского ун-та. 236 с. С. 138-142. 
Молчанова, О. Т. (1979) Топонимический словарь Горного Алтая. ГорноАлтайск : Горно-Алтайское отделение Алтайского книжн. изд-ва. 398 с.

Молчанова, О. Т. (1982) Структурные типы тюркских топонимов Горного Алтая. Саратов : Изд-во Саратовского университета. 256 с.

Мурзаев, Э. М. (1974) Очерки топонимики. М. : Изд-во «Мысль». 382 с.

Наделяев, В. М. (1986) У истоков тувинского языка // Исследования по тувинской филологии : сборник статей / редкол.: Д. А. Монгуш (отв. ред.) и др. Кызыл : ТНИИЯЛИ. 156 с. С. 53-63.

Ондар, Б. К. (2007) Топонимический словарь Тувы. 2-е изд. Кызыл : Тувинское книжное издательство. 552 с.

Ондар, Б. К. (2008) Тувинская топонимия. Сопоставительный анализ топонимов Тувы с топонимией Южной Сибири и других тюркоязычных территорий. Кызыл : Тувинское книжное издательство. 304 с.

Ондар, Б. К. (2011) Русская топонимия Тувы. Кызыл : РИО ТувГУ. 168 с.

Радлов, В.В.(1989) Из Сибири : страницы дневника/под ред.С.И.Вайнштейна; пер. с нем. К. Д. Цивиной, Б. Е. Чистовой. М. : Наука. 749 с.

Рассадин, В. И. (2016) Тофаларско-русский словарь. М. : Издательский Дом ЯСК. 608 c.

Татаринцев, Б. И. (1973) Об особенностях топонимии северо-восточной Тувы // Происхождение аборигенов Сибири и их языков : Материалы Всесоюзной конференции 14-16 июня 1973 г. Томск : Изд-во Томского ун-та. 236 с. C. $142-144$.

Татаринцев, Б. И. (1977а) Местные географические термины северо-восточной Тувы // Советская тюркология. № 5. С. 19-21.

Татаринцев, Б. И. (1977b) О топонимии бассейна реки Каа-Хем // Тувинский язык и литература в послеоктябрьский период / отв. ред. Д. А. Монгуш. Кызыл : б/и. 187 с. С. $88-98$.

Татаринцев, Б. И. (1993) О некоторых древних топонимах тюркского происхождения на территории Тувы // Вопросы тувинского языкознания : сборник материалов / ред. Д. А. Монгуш, Б. И. Татаринцев. Кызыл : МП «Новости Тувы». 126 с. С. $105-113$.

Тувинско-русский словарь (1968) / под ред. Э. Р. Тенишева. М. : Советская энциклопедия. 646 с. 


\section{REFERENCES}

Bavuu-Syuryun, M. V. (2005) Struktura toponimov mongol'skogo proiskhozhdeniia na territorii Tuvy [The structure of toponyms of Mongol origin on the territory of Tuva]. In: Problemy etnokul'turnykh sviazei mongol'skikh i tiurkskikh narodov [Problems of ethnocultural links between Mongol and Turkic peoples] / Sampildendev Kh. et al.; ed. by A. L. Angarkhaev. Ulan-Ude, GUP «ID «Buriaad ynen». 351 p. Pp. 233-237. (In Russ.).

Bavuu-Syuryun, M. V. (2011) Puti formirovaniia zarubezhnykh dialektov tuvinskogo iazyka [Ways of formation of foreign dialects of Tuvan language]. In: Aktual'nye problemy dialektologii iazykov narodov Rossii : materialy XI mezhregional'noi konferentsii (Ufa, 19-21 oktiabria 2011 g.) [Urgent issues of studying dialects of peoples of Russia: Proceedings of 11th international conference] / [comp. by R. N. Karimova]. Ufa, IIIaL UNTs RAN. 213 p. Pp. 30-32. (In Russ.).

Bavuu-Syuryun, M. V. (2018) Istoriia formirovaniia dialektov i govorov tuvinskogo iazyka [The history of formation of foreign dialects of Tuvan language]: Thesis of Diss. ... Doctor of Philology. Novosibirsk. 49 p. (In Russ.).

Baiarsaikhan, B. (2000) Toponimy na territorii sumona Tsengel v Mongolii (na tuvinskom iazyke) [Placenames on the territory of sumon Tsengel in Mongolia]. In: Stanovlenie i razvitie nauki v Tuve. (Materialy Mezhd.konferentsii, posv. $k$ 70-letiiu tuvinskoi pis'mennosti 12-14 sentiabria 2000 g.) [The rise and development of research in Tuva: Proceedings of international conference devoted to the 70th anniversary of Tuvan writing, September 12-14, 2000]: in 2 vols. Kyzyl, RIO TuvGU. Vol. 1. 140 p. Pp. 23-25. (In Russ.).

Vainshtein, S. I. (1961) Tuvintsy-todzhintsy. Istoriko-etnograficheskie ocherki [Tozhu tuvans: historical and ethnographic essays]. Moscow, Nauka. 218 p. (In Russ.).

Drevnetiurkskii slovar' [An old Turkic dictionary] (1969) / ed. by V. M. Nadeliaev et al. Leningrad, Nauka. 676 p. (In Russ.).

Istoriia Tuvy [The History Of Tuva] (2001) : in 2 vol. 2nd ed / ed. by S. I. Vanshtein and M. Kh. Mannai-ool. Novosibirsk, Nauka. Vol. I. 367 p. (In Russ.).

Mannai-ool M. Kh. (2004) Tuvintsy: proiskhozhdenie i formirovanie tuvinskogo etnosa [Tuvans: the origin and formation of the Tuvan ethnos]. Novosibirsk, Nauka. 166 p. (In Russ.).

Molchanova, O. T. (1973) Mongol'skii sloi v toponimii Tuvy [Mongolian layer in Tuvan toponymy]. In: Proiskhozhdenie aborigenov Sibiri i ikh iazykov : Materialy Vsesoiuznoi konferentsii 14-16 iiunia $1973 \mathrm{~g}$. [The origin of aboriginal peoples of Siberia and their languages: Proceedings of All-Union conference, June 14-16, 1973]. Tomsk, Tomskii un-t Publ. 236 p. Pp. 138-142. (In Russ.).

Molchanova, O. T. (1979) Toponimicheskii slovar' Gornogo Altaia [A toponymical dictionary of Gorny Altai]. Gorno-Altaisk, Gorno-altaiskoe otdelenie Altaiskogo knizhn. izd-va. 398 p. (In Russ.). 
Molchanova, O. T. (1982) Strukturnye tipy tiurkskikh toponimov Gornogo Altaia [Structural types of Turkic toponyms in Gorny Altai]. Saratov, Saratovskii universitet Publ. 256 p. (In Russ.).

Murzaev, E. M. (1974) Ocherki toponimiki [Essays in toponymics]. Moscow, Mysl' Publ. 382 p. (In Russ.).

Nadeliaev, V. M. (1986) U istokov tuvinskogo iazyka [At the origins of the Tuvan language]. In: Issledovaniia po tuvinskoi filologii : sbornik statei [Studies in Tuvan philology: a collection of articles] / editorial board: D. A. Mongush (ed.) et al. Kyzyl, TNIIIaLI. 156 p. Pp. 53-63. (In Russ.).

Ondar, B. K. (2007) Toponimicheskii slovar' Tuvy [A toponymical dictionary of Tuva]. 2nd ed. Kyzyl, Tuvinskoe knizhnoe izdatel'stvo. 552 p. (In Russ.).

Ondar, B. K. (2008) Tuvinskaia toponimiia. Sopostavitel'nyi analiz toponimov Tuvy s toponimiei Iuzhnoi Sibiri i drugikh tiurkoiazychnykh territorii [Tuvan toponyms. A comparative analysis of toponyms of Tuva with those of southern Siberia and other Turkicspeaking territories]. Kyzyl, Tuvinskoe knizhnoe izdatel'stvo. 304 p. (In Russ.).

Ondar, B. K. (2011) Russkaia toponimiia Tuvy [Russian placenames in Tuva]. Kyzyl, RIO TuvGU. 168 p. (In Russ.).

Radlov, V. V. (1989) Iz Sibiri : stranitsy dnevnika [From Siberia: Pages from a diary] / ed. by C. I. Vainshtein; transl. from Germ. by K. D. Tsivina and B. E. Chistova. Moscow, Nauka. 749 p. (In Russ.).

Rassadin, V. I. (2016) Tofalarsko-russkii slovar' [A Tofalar-Russian dictionary]. Moscow, Izdatel'skii Dom IaSK. 608 p. (In Russ.).

Tatarintsev, B. I. (1973) Ob osobennostiakh toponimii severo-vostochnoi Tuvy [перевод на англ.]. In: Proiskhozhdenie aborigenov Sibiri i ikh iazykov : Materialy Vsesoiuznoi konferentsii 14-16 iiunia $1973 \mathrm{~g}$. [The origin of aboriginal peoples of Siberia and their languages: Proceedings of All-Union conference, June 14-16, 1973]. Tomsk, Tomskii un-t Publ. 236 p. Pp. 142-144. (In Russ.).

Tatarintsev, B. I. (1977a) Mestnye geograficheskie terminy severo-vostochnoi Tuvy [Local geographical terms of the north-eastern Tuva]. Sovetskaia tiurkologiia, no. 5, pp. 19-21. (In Russ.).

Tatarintsev, B. I. (1977b) O toponimii basseina reki Kaa-Khem [On the toponymy of the Kaa-Khem basin]. In: Tuvinskii iazyk i literatura $v$ posleoktiabr'skii period [Tuvan language and literature after the October revolution] / ed. by D. A. Mongush. Kyzyl, s. n. 187 p. Pp. 88-98. (In Russ.).

Tatarintsev, B. I. (1993) O nekotorykh drevnikh toponimakh tiurkskogo proiskhozhdeniia na territorii Tuvy [On some ancient toponyms of Turkic origin on the territory of Tuva]. In: Voprosy tuvinskogo iazykoznaniia [Issues of Tuvan linguistics]: collection of materials / ed. by D. A. Mongush and B. I. Tatarintsev. Kyzyl, MP «Novosti Tuvy». 126 p. Pp. 105-113. (In Russ.). 
Tuvinsko-russkii slovar'. Okolo 22 tysiach slov [A Tuvan-Russian dictionary. C. 20,000 words] (1968) / ed. by E. R. Tenishev. Moscow, Sovetskaia entsiklopediia Publ. 646 p. (In Russ.).

Submission date: 01.06.2018.

\section{Для циттирования:}

Бавуу-Сюрюн М. В. Топонимы как маркеры диалектов и говоров тувинского языка [Электронный ресурс] // Новые исследования Тувы. 2018, № 3. URL: https://nit. tuva.asia/nit/article/view/786 (дата обращения: дд.мм.гг.). DOI: 10.25178/nit.2018.3.2

\section{For citation:}

Bavuu-Surun M. V. Place names as markers of the dialects and sub-dialects of Tuvan language. The New Research of Tuva, 2018, no. 3 [on-line] Available at: https://nit.tuva.asia/ nit/article/view/786 (accessed:...). DOI: 10.25178/nit.2018.3.2 